\title{
A Study on The Counselors' Levels of Professional Pride And Job Satisfaction According to Certain Variables
}

\author{
Hacer Yıldırım-Kurtuluş* \\ School Counseling Service, Ministry of Education, Istanbul, Turkey \\ ORCID: 0000-0002-0880-1318
}

\section{Fulya Yüksel-Şahin}

Yildiz Technical University, Department of Educational Sciences, Division of Psychological Counseling and Guidance, Istanbul, Turkey

ORCID: 0000-0003-3454-2142

Article history

Received:

10.06.2020

Received in revised form: 09.03.2021

Accepted:

12.03.2021

Key words:

Psychological Counselor, Professional Pride,

Professional Satisfaction, Supervision
The study examines whether counselors' levels of professional pride and job satisfaction significantly differ according to gender, education level, receiving supervision for individual counseling, receiving supervision for group counseling, seeing university education as adequate, the job title used, and seniority. The study group consisted of 661 counselors. Of the participants, $71.6 \%$ are female $(\mathrm{n}=473)$ and $28.4 \%(\mathrm{n}=188)$ are male; and as for their age ranges, $71.3 \%(\mathrm{n}=471)$ are between $21-30$ years, $20.0 \%$ $(n=132)$ are between $31-40$ years, $7.6 \%(n=50)$ are between $41-50$ years, and $1.2 \%(\mathrm{n}=8)$ are between 51-60 years of age. The "Professional Pride Scale", the "Job Satisfaction Scale", and a "Personal Information Form" were used to collect the study data. Data analysis was based on MANOVA, Games-Howell Test, Scheffe Test, and Discriminant Analysis. The results demonstrate that the counselors' mean scores in professional pride and job satisfaction do not significantly differ according to gender and receiving supervision for individual and group counseling. On the other hand, significant differences were found between the counselors' mean scores in professional pride and job satisfaction according to education level, seeing university education as adequate, and the job title used. As for seniority, the counselors' mean score in professional pride significantly differed, while their mean scores in job satisfaction did not significantly differ according to seniority. The study results are discussed in light of the literature and certain suggestions are made accordingly.

\section{Introduction}

The professions that provide mental health services include psychiatrists, clinical psychologists, psychiatric nurses, and counselors. Counselors are specialists in providing counseling services (Patterson and Welfel, 1994). Counseling is a professional relationship

\footnotetext{
* Correspondency: haceryildirim91@gmail.com
} 
that empowers diverse individuals, families, and groups to accomplish mental health, wellness, education, and career goals (ACA-American Counseling Association, 2016). Serving as a counselor requires possessing the theoretical and practical knowledge and skills (Yüksel-Şahin, 2019). Concordance between their capabilities, knowledge and skills during practice and the activities required by the profession allows counselors to have positive feelings toward their profession and feel in harmony with it. Positive feelings of counselors toward their professional identity have been termed as professional pride in the literature. Swickert (1997) highlighted feeling proud of the profession when defining counselors' professional identity. Professional pride has been defined as the feelings of respect for one's own and others' professions (Kernaghan, 2001) and positive emotions felt for being supported for one's professional achievements (Jahsen, 2010). According to Vermeeren En Van Geest (2012), employees who are proud of their profession are individuals who make use of their experiences and knowledge acquired through education, comply with the rules of professional ethics, and have professional motivation.

Having professional pride is closely associated with the training, professional applications, and professional identity of counselors (Haverkamp, Robertson, Cairns, and Bedi, 2011). Remley and Herlihy (2007) refer to the concept of professional pride as one of the six subdimensions of the professional counselor identity. A comprehensive professional counselor identity consists of the following sub-dimensions: a)having knowledge and understanding about the history of the profession, b) understanding the philosophical foundations of the profession, c) knowing the professional responsibilities and defined roles of counselors as well as the distinctions between counseling and other mental health professions, d) feeling proud of being a member of the profession, e) participating in professional organizations and defending the profession, and f) being informed about the code of ethics for the counseling profession. Among these dimensions, concept of professional pride refers to appreciating the profession's philosophy, values and history, feeling proud when practicing the profession and communicating this pride to others. Professional pride is an important factor for developing a comprehensive professional counselor identity. Professionals can feel proud of their profession by appreciating its historical development, fulfilling their currently applied professional roles and responsibilities, and through working for professional development (VanZandt, 1990). Myers, Sweeney and White (2002) argue that counselors with strong professional identities appreciate their profession as a result of their professional perceptions, qualities and knowledge. Individuals' efforts to fulfill their professional roles, improve themselves professionally and participate in professional activities result from professional pride.

Scanlan, Meredith, and Poulsen (2013) noted that a person will have greater professional commitment, job satisfaction, and more positive feelings about his/her profession when s/he is performing the profession in an effective manner. It is another very important factor for counselors to have positive feelings for being a member of the profession with sufficient knowledge and skills and experience job satisfaction by participating in working life with professional pride. Positive reframing of one's profession, positive and negative affectivity, and professional pride increase an individual's job satisfaction levels (Hayes, Bonner and Pryor, 2010). Baggerly and Osborn (2006) argued that counselors with high professional selfefficacy have fewer negative feelings and ideas about their profession and greater job satisfaction. Job satisfaction occupies a significant place in human life and is defined as the degree to which individuals are happy with their occupations. In addition, self-evaluation of the degree to which one is satisfied with the practiced profession and its opportunities is an important indicator of satisfaction or dissatisfaction with one's profession (Çetinkanat, 2000; 
Tezer, 1991). Hoppock defines job satisfaction as employees' emotional reactions towards their job (Mercer, 1997). According to Şimşek-Akgemci and Çelik (2007), job satisfaction is the happiness felt by one for being productive with his/her professional circle, to which s/he happily belongs, and making monetary gains for such production. Miner (1992) construes the concept of job satisfaction in a more general sense as all the feelings and thoughts held about a profession by the members of that profession may be worth evaluating in this regard.

Job satisfaction depends on how much an individual values various factors such as the capabilities and skills required by professional tasks, cleanliness, order and interpersonal relations in the work environment, income level, reward and recognition, social security, promotion chances, authority and responsibility, competition, and the chance to distinguish oneself, as well as daily working hours (Alçekiç, 2001). If one can see the tangible product of his/her work, then his/her feelings of pride become a source of satisfaction. Furthermore, job satisfaction is greater if an employee receives material and immaterial recompense for his/her efforts. The greater the degree to which one's job corresponds to his/her values, the higher the job satisfaction gets (Şimşek-Akgemci and Çelik, 2007). Job satisfaction leads to positive effects on both mental health and professional qualities and productivity (Locke, 1998; Karadăg, Sertbaş, Güner, Taşdemir and Özdemir, 2002). In a similar vein, Matrunola (1996) noted that reduced satisfaction with one's profession results in increased negative affectivity such as anger, stress and sorrow, which may in turn cause a decline in one's professional qualities and motivation. On the other hand, job satisfaction fills the members of the profession with feelings of achievement and content (Galanou, Georgakopoulos, Sotiropoulos and Dimitris, 2010). Professionals develop positive feelings and ideas about their jobs when their professional expectations are met (Kadıoğlu, 2014). Obviously, people who are satisfied with their professions are more productive, creative and effective in their professional practice. Counselors' thoughts, feelings and behaviors are also influenced by whether they are satisfied with their profession. In Turkey, counseling presents some challenges as a developing profession. Among such challenges are prejudices and lack of understanding, unrealistic expectations, unclear boundaries of the profession, low pay, the high number of students per counselor, and too much paperwork. All these create negative thoughts and feelings about the profession among its members and negatively affects their professional pride and job satisfaction (Tuzgöl-Dost and Keklik, 2012). Recent years have witnessed an increase in research on professional pride (Borst and Lako, 2017; Kim, Lee, Jeon and Kim, 2019; Leeman and Volman, 2019; Vikström and Johansson, 2019) and job satisfaction (Torres, 2019; Samuel, Sharma and Sharma, 2020) in international literature. On the other hand, in Turkey, there is much less research on counselors' professional job (Recepoğlu and Tümlü, 2015; İnce and Şahin, 2016; İbrahim and Dikmenli, 2019), and a limited number of studies have been conducted on counselors' professional pride (Apakay and Karairmak, 2019; Gümüş, 2017). Therefore, the present study aims to examine counselors' levels of professional pride and job satisfaction according to gender, education level, receiving supervision for individual counseling, receiving supervision for group counseling, seeing university education as adequate, the job title used, and seniority. We believe that this study will contribute to the literature as it examines the factors that affect counselors' professional pride and job satisfaction, attempts to reveal the positive and negative conditions they are faced with while performing their profession, and aims to improve the quality of psychological counseling profession. It is also believed to contribute to the profession's development and the well-being of psychological counselors by identifying the factors that negatively affect counselors' levels of professional pride and job satisfaction.

The main problematic of the study is then the question "do counselors" professional pride and 
job satisfaction significantly differ according to certain variables?". In order to make a detailed inquiry about the problem question/purpose, we sought answers to the following subproblems/purposes.

(1) Do the counselors' levels of professional pride and job satisfaction significantly differ according to gender?

(2) Do the counselors' levels of professional pride and job satisfaction significantly differ according to education level?

(3) Do the counselors' levels of professional pride and job satisfaction significantly differ according to receiving supervision for individual counseling?

(4) Do the counselors' levels of professional pride and job satisfaction significantly differ according to receiving supervision for group counseling?

(5) Do the counselors' levels of professional pride and job satisfaction significantly differ according to seeing university education as adequate?

(6) Do the counselors' levels of professional pride and job satisfaction significantly differ according to the job title used?

(7) Do the counselors' levels of professional pride and job satisfaction significantly differ according to seniority?

\section{Methodology}

\section{Research Model}

This study uses the survey research model, which is a quantitative research model. Survey model is a research model that is used to find out the participants' opinions or interests, skills, abilities, attitudes and alike about a specific subject or situation and is often conducted on relatively larger samples to study the intervariable correlations (Karasar, 2009).

\section{Study Sample}

The study universe consists of 4310 psychological counselors working at public schools (kindergartens-primary schools-secondary schools-high schools) and Guidance Research Centers in İstanbul, Turkey. The participants include 661 counselors who were selected using convenient sampling method. All of these participants graduated from the Psychological Counseling and Guidance Departments at different universities in Turkey or the Turkish Republic of Northern Cyprus. Our criteria required the participants to graduate from the departments of psychological counseling guidance and received the individual and group counseling applications course during their undergraduate training. Table 1 shows the information on the participants.

Table 1: Information on the Participants

\begin{tabular}{lll}
\hline Variables & $\mathbf{n}$ & $\mathbf{\%}$ \\
\hline Gender & & 71.6 \\
Female & 473 & 28.4 \\
Male & 188 & 71.3 \\
\hline Age & & 20.0 \\
21-30 years old & 471 & 7.6 \\
31-40 years old & 132 & 1.2 \\
41-50 years old & 50 & \\
51-60 years old & 8 & 47.8 \\
\hline Seniority & & \\
$0-5$ years & 316 & \\
\hline
\end{tabular}




\begin{tabular}{lll}
\hline 6-11 years & 228 & 34.5 \\
12-17 years & 55 & 8.3 \\
18-23 years & 47 & 7.1 \\
24 years and above & 15 & 2.3 \\
\hline Educational institution & & \\
Pre-school & 33 & 5.0 \\
Primary school & 156 & 23.6 \\
Middle school & 243 & 36.8 \\
High school & 189 & 28.6 \\
Guidance and Research Center & 40 & 6.1 \\
\hline
\end{tabular}

\section{Assessment (Data Collection) Instruments Used in the Study}

Counselor Professional Pride Scale: The Professional Pride Scale is a subscale of the Counselor Professional Identity Measure developed by Emerson (2010). This subscale was adapted to Turkish by Gümüş (2017) under the title "Counselor Professional Pride Scale" (CPPS). The six-item Likert-type scale is a unidimensional scale with 11 items. In order to test the construct validity of the CPPS, it was subjected to exploratory factor analysis (EFA) with principal components analysis. The unrestricted analysis indicated an 11-item, threefactor (common variance 57\%) structure. Yet, the analysis was repeated as certain items had very low loadings. When the analysis was restricted to a single factor, the common variance accounted for was $39 \%$ and item loadings ranged between .27 and .82 . The scale has a Cronbach's Alpha coefficient of .76.

Job Satisfaction Scale: Developed by Kuzgun, Sevim and Hamamc1 (2005), this scale is a five-point Likert-type scale with 20 items. The high assessment scores obtained by the scale indicate a high level of job satisfaction. The results of the factor analysis performed to assess the scale's construct validity revealed that the items' factor loadings range between .47 and .88. Furthermore, the two items identified through the analysis account for a total variance of $48.6 \%$. On the other hand, correlation of each item score with the total score was above .30 . The Cronbach's Alpha coefficient for the scale was found to be .90 .

Informed Consent Form and Personal Information Form: Prior to the administration of the scales, an Informed Consent Form was used to obtain consent of the participants, all of whom participated in the study voluntarily. The Personal Information Form involves questions to identify the counselors' gender, age, professional experience, education level, the job title they use, the number of supervision sessions taken for individual and group counseling throughout university education, and self-perceptions about the adequacy of university education.

\section{Data Collection Process}

In order to examine whether the counselors' levels of professional pride and job satisfaction significantly differ according to gender, education level, receiving supervision for individual counseling, receiving supervision for group counseling, seeing university education as adequate, the job title used, and seniority, the "Counselor Professional Pride Scale", the "Job Satisfaction Scale", and the "Personal Information Form" were used as the data collection instruments in the study. Required permissions to use the data collection instruments were obtained via e-mail from the developers and adaptors of the Counselor Professional Pride Scale and the Job Satisfaction Scale. Upon obtaining permissions for the scales, the researchers then obtained a "Research Permit" from the Social Sciences Institute of Y1ldız Technical University and the "Ethics Committee Approval" from the Academic Ethics Committee of Yildiz Technical University indicating that no unethical practice is involved. In 
addition, another permit was obtained from Istanbul Provincial Directorate of National Education since the study data would be collected from the psychological counselors working in preschools, primary, secondary, and high schools and the Guidance Research Centers in Istanbul, all of which are run by the Ministry of National Education (MoNE). The data collection process started in October 2018 and ended in March 2019.

Also, the assessment instruments were converted into a link using Google Forms to be completed in an electronic format. 110 of the responses were collected in an electronic environment. The remaining 551 data were collected either through group and individual administering of the data collection process and a total of 662 individuals were reached in this regard. Group administrations were carried out prior to the meetings held by the Guidance Research Centers at the beginning of both semesters of 2018-2019 academic year and also before their in-service training sessions. Prior to the group administration of the assessment instruments, we contacted the director of the relevant Guidance Research Center to obtain permission for administering the very process before the meeting/seminar. Individual administrations were done by visiting the schools and reaching the counselors working there. Prior to each administration session, the researcher introduced herself and the study's purpose and significance. Potential participants were informed that participation is voluntary, no individual assessment would be made, they would not be asked for any identity information, and the data would only be used for scientific purposes. The volunteers then signed the "Informed Consent Form", which includes these explanations as well as information pertaining to the research, and completed the dataset.

\section{Data Analysis}

SPSS 22 software was used for data analysis. In order to ascertain whether the scores on the "Counselor Professional Pride Scale" and the "Job Satisfaction Scale" as the dependent variables of the study show a normal distribution, the skewness and kurtosis coefficient values were calculated for the scale scores. The Box M Test was used to test the homogeneity of variance and covariance matrices (Büyüköztürk, 2002). As a result of the analysis, MANOVA Wilks Lambda $(\lambda)$ Test was performed in cases where variance-covariance homogeneity was achieved, while MANOVA-Pillai's Trace Test was applied in cases where variancecovariance homogeneity was not achieved, without for the requirement for this condition. In the presence of any significant difference as a result, Games-Howell and Scheffe complementary tests were performed to identify the groups with the difference. In addition, Discriminant Analysis Test was applied in cases where the results of the MANOVA Test were significant and the results of the ANOVA Test were insignificant. The significance level was taken to be .05 for the study.

\section{Results}

In order to ascertain whether the scores obtained in the "Counselor Professional Pride Scale" and the "Job Satisfaction Scale" as the study variables have a normal distribution, we calculated the skewness and kurtosis coefficients for the scores. The skewness coefficients are $\mathrm{S}=.76$ for the Professional Pride Scale and $\mathrm{S}=.57$ for the Job Satisfaction Scale. And the kurtosis coefficients are $\mathrm{K}=.68$ for Professional Pride and $\mathrm{K}=.07$ for Job Satisfaction. Having skewness and kurtosis values ranging from -2 to +2 is acceptable indicating that the dataset shows a normal distribution (Bachman, 2004). The Box's M Test performed to test the homogeneity of the variance and covariance matrices yielded the following results: Box's M $=3.32(p>.05)$ for gender, Box's $\mathrm{M}=23.11(p<.05)$ for education level, Box's $\mathrm{M}=33.56$ $(p<.05)$ for receiving supervision for individual counseling, Box's $\mathrm{M}=29.89(p<.05)$ for 
receiving supervision for group counseling, Box's $\mathrm{M}=12.94(p=.05)$ for seeing university education as adequate, Box's $\mathrm{M}=20.34(p<.05)$ for the job title used, and Box's $\mathrm{M}=13.95$ $(p>.05)$ for seniority. Moreover, the intervariable correlation coefficients are smaller than .70, which attests to the absence of multiple connections among the variables.

The study sought an answer to the question "Do counselors' levels of professional pride and job satisfaction significantly differ according to gender, education level, receiving supervision for individual counseling, receiving supervision for group counseling, seeing university education as adequate, the job title used, and seniority?" To find the answer, MANOVAWilks Lambda $(\lambda)$ Test and MANOVA-Pillai's Trace Test were carried out and the analysis results are given in the following Tables.

Table 2. The Results of the MANOVA-Wilks Lambda Test on the Differences among Counselors' Professional Pride and Job Satisfaction according to Gender

\begin{tabular}{|c|c|c|c|c|c|c|c|c|}
\hline Source & Variables & $\begin{array}{l}\text { Sum } \\
\text { Squares }\end{array}$ & of & $S d$ & $\begin{array}{l}\text { Mean } \\
\text { Squares }\end{array}$ & of & $p$ & $\eta^{2}$ \\
\hline \multirow[t]{2}{*}{ Gender } & P. Pride & 12.62 & & 1 & 12.62 & .48 & .49 & .00 \\
\hline & J. Satisfaction & 10.01 & & 1 & 10.01 & .07 & .79 & .00 \\
\hline
\end{tabular}

Wilks Lambda $(\lambda)$ Test $=.998, F$ calcutated $(2,658)=.61 p>.05, \eta^{2}=.00$

\begin{tabular}{lllll}
\hline & Gender & $\mathbf{N}$ & $\overline{\mathbf{x}}$ & Ss \\
\hline P. Pride & Female & 473 & 46.85 & 4.98 \\
& Male & 188 & 46.55 & 5.55 \\
\hline J. Satisfaction & Female & 473 & 75.89 & 11.46 \\
& Male & 188 & 76.16 & 11.93 \\
\hline
\end{tabular}

As seen in Table 2, the counselors' professional pride and job satisfaction scores do not significantly differ according to gender. The impact value was also low (Wilks Lambda $\lambda$ Test $=.998, \mathrm{~F}$ calculated $(2,658)=.61, p>.05, \eta 2=.00)$.

Table 3. The Results of the MANOVA-Pillai's Trace Test on the Differences among Counselors' Professional Pride and Job Satisfaction according to Education Level

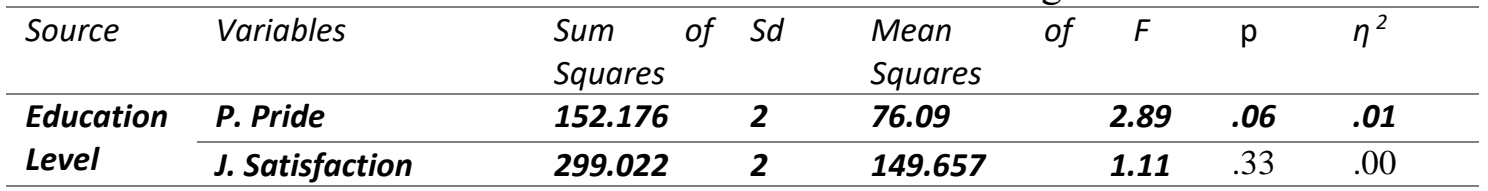

Pillai's Trace Test $=.02$, F calcutated $(4,1316)=3.01 \mathrm{p}<.05, \eta^{2}=.01$

\begin{tabular}{lllll}
\hline & Education & n & $\overline{\mathbf{x}}$ & Ss \\
\hline $\boldsymbol{P .}$ Pride & Undergraduate & 487 & 46.81 & 4.91 \\
& Master's & 164 & 46.87 & 5.47 \\
& PhD & 10 & 42.90 & 9.21 \\
\hline J. Satisfaction & Undergraduate & 487 & 75.58 & 11.71 \\
& Master's & 164 & 77.14 & 11.25 \\
& PhD & 10 & 75.80 & 11.43 \\
\hline
\end{tabular}

As seen in Table 3, the counselors' professional pride and job satisfaction scores significantly differ according to education level. The impact value was found to be low (Pillai's Trace Test $=.02, \mathrm{~F}$ calculated $\left.(4,1316)=3.01 p<.05, \eta^{2}=.01\right)$. However, according to the ANOVA results given as an extension of MANOVA in Table 1, it was found that the counselors' professional pride scores (F calculated $=2.89, p>.05, \quad \eta^{2}=.01$ ) and job satisfaction scores ( $F$ calculated $=1.11, p>.05, \eta^{2}=.00$ ) do not significantly differ according to education level. The impact of magnitude (Eta Square) values are $\eta 2=.01$ for professional pride and $\eta^{2}=.00$ 
for job satisfaction with a low level of calculated impact.

As seen in Table 3, upon obtaining significant results for the MANOVA Test and insignificant results for the ANOVA Test, a Discriminant Analysis Test was performed and the results are shown in Table 4. Discriminant Analysis Test was applied to the professional pride and job satisfaction scores so as to identify the source of the difference.

Table 4. The Results of the Discriminant Analysis Test for Education Level

The Results of the Canonical Discriminant Function Test for the Function Calculated for Education Level

\begin{tabular}{llllllll}
\hline Function & Eigenvalue & $\begin{array}{l}\boldsymbol{\%} \\
\text { Variance }\end{array}$ & $\begin{array}{l}\text { Canonical } \\
\text { Correlation }\end{array}$ & $\begin{array}{l}\text { Wilks } \\
\text { Lambda }\end{array}$ & $\mathbf{X}^{\mathbf{2}}$ & Sd & $\boldsymbol{p}$ \\
\hline $\mathbf{1}$ & .02 & 83.5 & .12 & .982 & 12.00 & 4 & .02 \\
$\mathbf{2}$ & .00 & 16.5 & .06 & .997 & 1.99 & 1 & .16 \\
\hline
\end{tabular}

Standardized Canonical Discriminant Function Coefficients and Structure Matrix Results for the Discriminant Function

\begin{tabular}{lcccc}
\hline Factors & \multicolumn{2}{l}{$\begin{array}{l}\text { Standardized Canonical Discriminant } \\
\text { Function Coefficients }\end{array}$} & Structure Matrix & \\
& $\mathbf{1}$ & $\mathbf{2}$ & $\mathbf{1}$ & $\mathbf{2}$ \\
Professional Pride & 1.24 & .21 & .68 & $.73 *$ \\
Job Satisfaction & -.92 & .86 & -.17 & $.99 *$ \\
\hline
\end{tabular}

Correct Categorization Ratio: $43.7 \%$

In discriminant analysis, a discriminant function is generated (implicit variable) using a linear combination of one or more quantitative predictive variables/independent variables. The significance level of the discriminant function is assessed based on canonical correlation, eigenvalue and Wilks Lambda $(\lambda)$ values (Çokluk, Şekercioğlu and Büyüköztürk, 2016). As shown in Table 4, two functions were generated. Eigenvalues are .02 for the first function and .00 for the second function, which are low values. Although it is not clearly defined, an eigenvalue over .40 is accepted as "good" for the Canonical Discriminant Function Test (Çakmak and Gürdal, 2015). As a result, the functions generated for education level do not provide good discrimination.

As seen in Table 4, the canonical correlation value for the discriminant function is.12 for the first function and .06 for the second function. Canonical correlation is the relationship between professional pride and job satisfaction as the discriminant function using the groups based on education level. A canonical correlation of zero indicates the lack of any relations between the function and the groups. A higher correlation value indicates a high level of relationship (Çokluk, Şekercioğlu and Büyüköztürk, 2016). The squared canonical correlation value gives the accounting ratio. In other words, the first discriminant function obtained in the model accounts for $01 \%$ of group discrimination, while the second discriminant analysis accounts for $00 \%$ of group discrimination. This finding indicates that the discriminant functions are $01 \%$ effective in separating groups.

As seen in Table 4, the Wilks Lambda $(\lambda)$ Test and Chi-Square $\left(X^{2}\right)$ Test values were examined to ascertain whether the function based on education level is significant. As a result of the analysis, the values of Wilks Lambda $(\lambda)$ Test $=.98$ and $X^{2}=12.00, p<.05$ for the first function were found to be significant. This means that the function's separation power is significantly high and the groups are separated with a discriminant function. On the other hand, according to the analysis results, the Wilks Lambda $(\lambda)$ Test=.99 and $X^{2}=1.99, p>.05$ 
values were not found to be significant for the second function. In other words, the separation power of the second function is insignificant.

The Standardized Canonical Discriminant Function coefficients indicate the partial significance of the independent variables-predictive variable when estimating the impact of each dependent variable (on education level). This corresponds to the Beta Coefficient in regression analysis (Çokluk, Şekercioğlu and Büyüköztürk, 2016). For this purpose, we calculated the Standardized Canonical Discriminant Function Coefficients and Structure Matrix and these results are also shown in Table 4. For Standardized Canonical Discriminant Function coefficients, small values indicate low contribution, while large values indicate great contribution (Siyez and Kaya, 2011). Structure matrix is used to determine the significance of independent variables. This matrix indicates the correlation of each independent variablepredictive variable (professional pride and job satisfaction) with the discriminant function. As is clear from the Standardized Canonical Discriminant Function Coefficients given in Table 4, the highest coefficients on the first function are professional pride $(S K D F K=1.24)$ and job satisfaction $(S K D F K=.92)$, respectively. The highest coefficients on the second function are job satisfaction $(S K D F K=.86)$ and professional pride $(S K D F K=.21)$, respectively. As shown by the results of the structure matrix, the independent variable with the highest correlation with the first discriminant function obtained is professional pride $(Y M=.68)$, which is followed by job satisfaction $(Y M=.17)$. On the other hand, the independent variables with the highest correlation with the second discriminant function is job satisfaction $(Y M=.99 *)$, followed by professional pride $(Y M=.73)$.

A second look at Table 3 in light of all this information will show that the mean professional pride score for the counselors with a bachelor's degree $(\overline{\mathrm{x}}=46.81)$ and the mean professional pride score for the counselors with a master's degree $(\overline{\mathrm{x}}=46.87)$ are similar. Yet, the mean professional pride score for the counselors with a $\mathrm{PhD}$ degree $(\overline{\mathrm{x}}=42.90, \mathrm{Ss}=9.21, \mathrm{n}=10)$ is relatively lower. The professional pride of the PhD-holder counselors is separated from that of the counselors with bachelor's and master's degrees.

Table 3 also shows that the mean job satisfaction score of the counselors with a bachelor's degree $(\overline{\mathrm{x}}=75.58)$ and the mean job satisfaction score of the counselors with a $\mathrm{PhD}$ degree $(\mathrm{x}=75.80)$ were found to be similar. On the hand, the counselors with a master's degree have a higher mean job satisfaction score $\left(\mathrm{x}^{-}=77.14\right)$. Consequently, the job satisfaction of the counselors with a master's degree is separated from that of those with bachelor and $\mathrm{PhD}$ degrees. Moreover, the correct categorization ratio for the analysis is $43.7 \%$.

Table 5. The Results of the MANOVA-Pillai's Trace Test on the Differences among Counselors' Professional Pride and Job Satisfaction according to Receiving Supervision for Individual Counseling

\begin{tabular}{|c|c|c|c|c|c|c|c|c|c|}
\hline Source & Variables & $\begin{array}{l}\text { Sum } \\
\text { Squares }\end{array}$ & of & $S d$ & $\begin{array}{l}\text { Mean } \\
\text { Squares }\end{array}$ & of & $F$ & $\mathrm{p}$ & $\eta^{2}$ \\
\hline \multirow{2}{*}{$\begin{array}{l}\text { Individual } \\
\text { Counseling for } \\
\text { Super. }\end{array}$} & P. Pride & 256.002 & & 6 & 42.667 & & 1.62 & 14 & .02 \\
\hline & J. Satisfaction & 437.057 & & 6 & 72.843 & & .54 & .78 & .01 \\
\hline
\end{tabular}

Pillai's Trace Test $=.028, F$ calculated $(12,1308)=1.54 p>.05, \eta^{2}=.01$

\begin{tabular}{|c|c|c|c|c|}
\hline & Supervision & $\mathbf{n}$ & $\overline{\mathbf{x}}$ & Ss \\
\hline \multirow{4}{*}{ P. Pride } & I have not received supervision & 136 & 45.88 & 5.03 \\
\hline & 1-5 Sessions & 175 & 46.38 & 5.77 \\
\hline & 6-10 Sessions & 213 & 47.42 & 4.88 \\
\hline & 11-15 Sessions & 60 & 47.37 & 4.33 \\
\hline
\end{tabular}




\begin{tabular}{lllll}
\hline & 16-20 Sessions & 48 & 46.75 & 4.88 \\
& 21-25 Sessions & 15 & 46.93 & 5.84 \\
& 26 Sessions and More & 14 & 47.64 & 4.83 \\
\hline \multirow{3}{*}{ Satisfaction } & I have not received supervision & 136 & 75.73 & 11.97 \\
& 1-5 Sessions & 175 & 75.82 & 11.89 \\
& 6-10 Sessions & 213 & 75.74 & 11.50 \\
& 11-15 Sessions & 60 & 75.80 & 11.75 \\
& 16-20 Sessions & 48 & 77.18 & 11.78 \\
& 21-25 Sessions & 15 & 75.26 & 7.07 \\
& 26 Sessions and More & 14 & 80.85 & 8.24 \\
\hline
\end{tabular}

As seen in Table 5, the counselors' professional pride and job satisfaction scores do not significantly differ according to receiving supervision for individual counseling. And the impact value was found to be low (Pillai's Trace Test $=.028, \mathrm{~F}$ calculated $(12,1308)=1.54$ $\left.p>.05, \eta^{2}=.01\right)$. As seen from the ANOVA results given as an extension of the MANOVA results in Table 1 , the counselors' professional pride $\left(\mathrm{F}\right.$ calculated $\left.=1.62, p>.05, \eta^{2}=.02\right)$ and job satisfaction ( $\mathrm{F}$ calculated $=.54, p>.05, \eta^{2}=.01$ ) scores were found to not significantly differ according to receiving supervision for individual counseling. The impact of magnitude (Eta Square) values is $\eta 2=.02$ for professional pride and $\eta^{2}=.01$ for job satisfaction, indicating a low calculated impact.

Table 6. The Results of the MANOVA-Wilks Lambda Test on the Differences among Counselors' Professional Pride and Job Satisfaction according to Receiving Supervision for Group Counseling

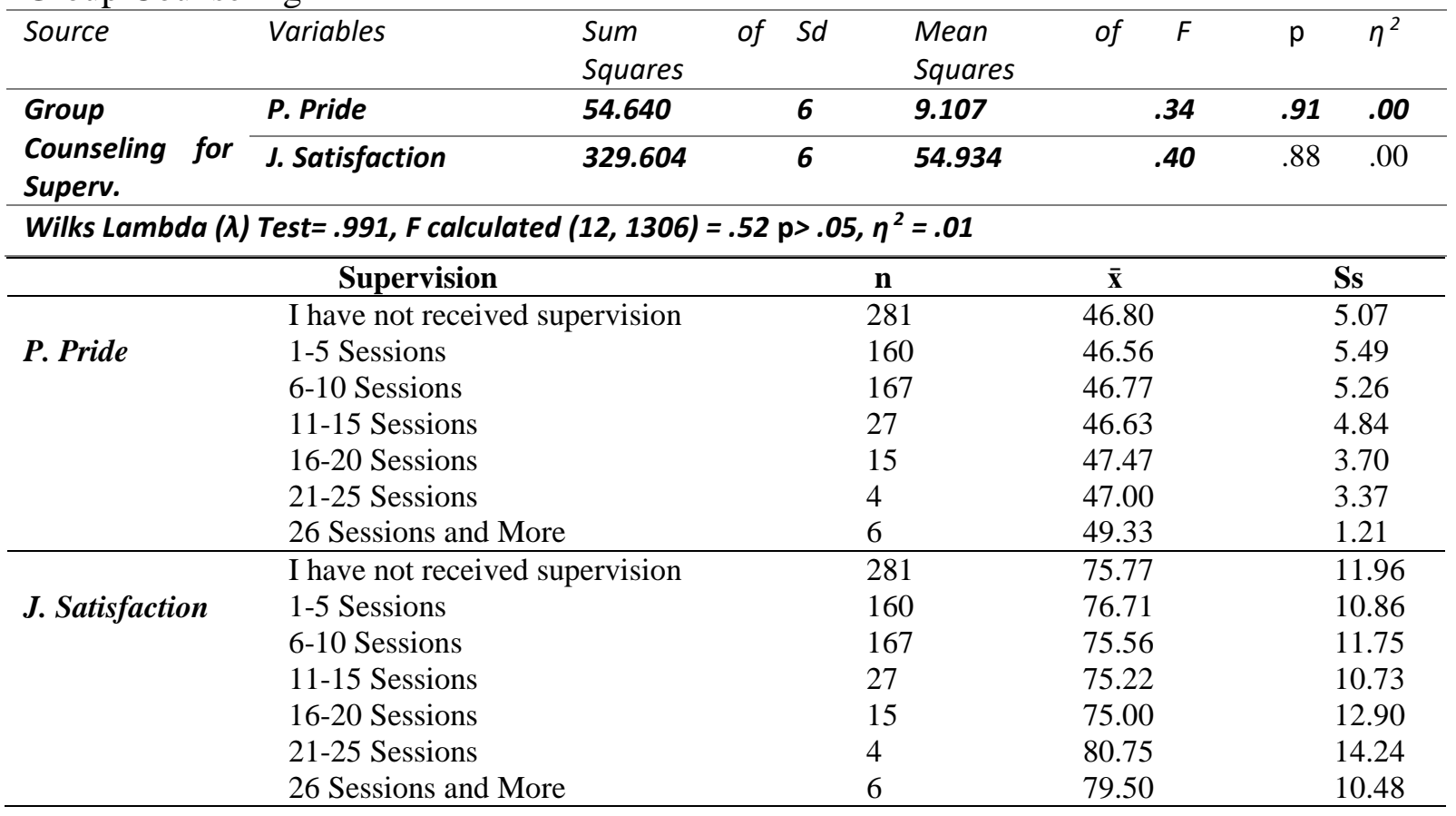

As seen in Table 6, the counselors' professional pride and job satisfaction scores do not significantly differ according to receiving supervision for group counseling. The impact value was low (Wilks Lambda $(\lambda)$ Test $=.991, F$ calculated $\left.(12,1306)=.52 p>.05, \eta^{2}=.01\right)$. As seen in the ANOVA results given in the MANOVA extension in Table 1, the counselors' professional pride scores (F calculated $\left.=.34, p>.05, \eta^{2}=.00\right)$ and job satisfaction scores $(\mathrm{F}$ calculated $\left.=.40, p>.05, \eta^{2}=.00\right)$ do not significantly differ according to receiving supervision for group counseling. The magnitude of impact (Eta Square) values were calculated as $\eta 2=.00$ for professional pride and $\eta^{2}=.00$ for job satisfaction. 
Table 7. The Results of the MANOVA-Pillai's Trace, Games Howell Tests on the Differences among Counselors' Professional Pride and Job Satisfaction according to Seeing University Education as Adequate

\begin{tabular}{|c|c|c|c|c|c|c|}
\hline Source & Sum of Squares & Sd & $\begin{array}{l}\text { Mean } \\
\text { Squares }\end{array}$ & of & $\mathrm{p}$ & $\eta^{2}$ \\
\hline \multirow{2}{*}{$\begin{array}{l}\text { Seeing } \\
\text { Education } \\
\text { Adequate }\end{array}$} & 521.635 & 2 & 260.817 & 10.11 & .00 & .03 \\
\hline & J. Satisfaction & 2 & 1096.817 & 8.34 & .00 & .03 \\
\hline \multicolumn{7}{|c|}{ Pillai's Trace Test $=.039, F$ calculated $(4,1316)=6.58 p<.05, \eta^{2}=.02$} \\
\hline & \multicolumn{2}{|c|}{ Seeing Education as Adequate } & $\mathbf{n}$ & $\overline{\mathbf{x}}$ & \multicolumn{2}{|r|}{ Ss } \\
\hline \multirow{3}{*}{ P. Pride } & Inadequate & & 193 & 45.45 & \multicolumn{2}{|r|}{5.63} \\
\hline & Moderately Adequate & & 381 & 47.16 & \multicolumn{2}{|r|}{4.87} \\
\hline & Highly Adequate & & 87 & 47.97 & \multicolumn{2}{|r|}{4.66} \\
\hline \multirow{3}{*}{ J. Satisfaction } & Inadequate & & 193 & 73.88 & \multicolumn{2}{|r|}{12.86} \\
\hline & \multirow{2}{*}{ Moderately Adequate } & & 381 & 76.13 & \multicolumn{2}{|r|}{10.94} \\
\hline & & & 87 & 79.89 & \multicolumn{2}{|r|}{10.35} \\
\hline \multirow[t]{2}{*}{ Games-Howell Tes } & \multicolumn{2}{|l|}{ Seeing Education as Adequate } & $\mathbf{1}$ & 2 & \multicolumn{2}{|r|}{3} \\
\hline & Inadequate & & - & $1.72 *$ & & $2.52 *$ \\
\hline \multirow[t]{2}{*}{ P. Pride } & \multicolumn{2}{|l|}{ Moderately Adequate (2) } & & - & \multicolumn{2}{|r|}{.80} \\
\hline & \multicolumn{2}{|l|}{ Highly Adequate (3) } & & & \multicolumn{2}{|r|}{-} \\
\hline \multirow{3}{*}{ J. Satisfaction } & \multirow{2}{*}{\multicolumn{2}{|c|}{$\begin{array}{l}\text { Inadequate } \\
\text { Moderately Adequate (2) }\end{array}$}} & - & 2.25 & \multicolumn{2}{|r|}{ 6.02* } \\
\hline & & & & - & & $3.77 *$ \\
\hline & \multicolumn{2}{|l|}{ Highly Adequate (3) } & & & \multicolumn{2}{|r|}{$\begin{array}{l}3.77^{*} \\
-\end{array}$} \\
\hline
\end{tabular}

As seen in Table 7, the counselors' professional pride and job satisfaction scores significantly differ according to whether they perceive university education as adequate. The impact value was calculated to be low (Pillai's Trace Test $=.039, \mathrm{~F}$ calculated $(4,1316)=6.58 p<.05, \eta^{2}$ $=.02$ ). As is shown by the ANOVA results given in the MANOVA extension in Table 1, the counselors' professional pride scores $\left(\mathrm{F}\right.$ calculated $\left.=10.11, p<.05, \eta^{2}=.03\right)$ and job satisfaction scores (F calculated $=8.34, p<.05, \eta^{2}=.03$ ) significantly differ according to whether they see university education as adequate. The impact of magnitude (Eta Square) values are $\eta 2=.03$ for professional pride and $\eta^{2}=.03$ for job satisfaction with a low calculated impact. The results of the Games-Howell Test demonstrate that the counselors who perceive university education as inadequate have a lower mean professional pride score than those of the counselors who perceive university education as moderately and highly adequate; the counselors who perceive university education as inadequate have a lower mean job satisfaction score than the counselors who perceive university education as moderately and highly adequate.

Table 8. The Results of the MANOVA-Pillai's Trace, Games Howell Tests on the Differences among Counselors' Professional Pride and Job Satisfaction according to the Job Title Used

\begin{tabular}{|c|c|c|c|c|c|c|c|}
\hline Source & Variables & Sum of Squares & Sd & $\begin{array}{l}\text { Mean } \\
\text { Squares }\end{array}$ & of & $\mathrm{p}$ & $\eta^{2}$ \\
\hline \multirow[t]{2}{*}{ the Job Title } & P. Pride & 804.652 & 3 & 268.217 & 10.55 & .00 & .05 \\
\hline & J. Satisfaction & 2780.759 & 3 & 926.920 & 7.09 & .00 & .03 \\
\hline \multicolumn{8}{|c|}{ Pillai's Trace Test $=.055, \mathrm{~F}$ calculated $(6,1312)=6.15 \mathrm{p}<.05, \eta^{2}=.03$} \\
\hline \multicolumn{3}{|c|}{$\begin{array}{c}\text { Title } \\
\end{array}$} & \multicolumn{2}{|c|}{$\mathbf{n}$} & $\overline{\mathbf{x}}$ & \multicolumn{2}{|c|}{ Ss } \\
\hline \multirow{4}{*}{ P. Pride } & \multicolumn{2}{|c|}{ Psychological counselor } & \multicolumn{2}{|r|}{308} & 47.38 & \multicolumn{2}{|c|}{5.06} \\
\hline & Counselor & & \multicolumn{2}{|r|}{94} & 44.10 & \multicolumn{2}{|c|}{5.79} \\
\hline & \multicolumn{2}{|c|}{ School psychological counselor } & & 223 & 46.92 & \multicolumn{2}{|c|}{4.68} \\
\hline & \multicolumn{3}{|c|}{ Guidance Specialist } & 36 & 47.44 & \multicolumn{2}{|c|}{4.91} \\
\hline
\end{tabular}




\begin{tabular}{|c|c|c|c|c|c|}
\hline \multirow{4}{*}{ J. Satisfaction } & Psychological counselor & 308 & & 77.70 & 11.12 \\
\hline & Counselor & 94 & & 71.60 & 13.08 \\
\hline & School psychological counselor & 223 & & 75.49 & 11.22 \\
\hline & Guidance Specialist & 36 & & 75.71 & 10.72 \\
\hline \multirow[t]{2}{*}{$\begin{array}{l}\text { Games-Howell } \\
\text { Test }\end{array}$} & Title & 1 & & 2 & 3 \\
\hline & Psychological counselor & & - & $3.27 *$ & - \\
\hline \multirow[t]{3}{*}{ P. Pride } & Counselor & & & - & - \\
\hline & School psychological counselor (3) & & & & - \\
\hline & Guidance Specialist & & & & \\
\hline \multirow{4}{*}{ J. Satisfaction } & Psychological counselor & & - & $6.10^{*}$ & - \\
\hline & Counselor & & & - & 2.82 \\
\hline & School psychological counselor (3) & & & & - \\
\hline & Guidance Specialist & & & & \\
\hline
\end{tabular}

As seen in Table 8, the counselors' professional pride and job satisfaction scores significantly differ according to the job title used. The impact value was low (Pillai's Trace Test $=.055, \mathrm{~F}$ calculated $\left.(6,1312)=6.15 p<.05, \eta^{2}=.03\right)$. As is clear from the ANOVA results given in the MANOVA extension in Table 1 , the counselors' professional pride scores (F calculated= $\left.10.55, p<.05, \eta^{2}=.05\right)$ and job satisfaction scores $\left(\mathrm{F}\right.$ calculated $=7.09, p<.05, \eta^{2}=.03$ ) significantly differ according to job title. The magnitude of impact (Eta Square) values are $\eta 2$ $=.05$ for professional pride and $\eta^{2}=.03$ for job satisfaction, with a low calculated impact. The results of the Games-Howell Test demonstrate that the mean professional pride score was found to be lower for the counselors who use "counselor" as their job title, when compared to the counselors who use "psychological counselor" as their job title; the mean job satisfaction score of the counselors who use "counselor" as their job title is lower than that of those who use the title of "psychological counselor".

Table 9. The Results of the MANOVA-Pillai's Trace Test on the Differences among Counselors' Professional Pride and Job Satisfaction according to Seniority

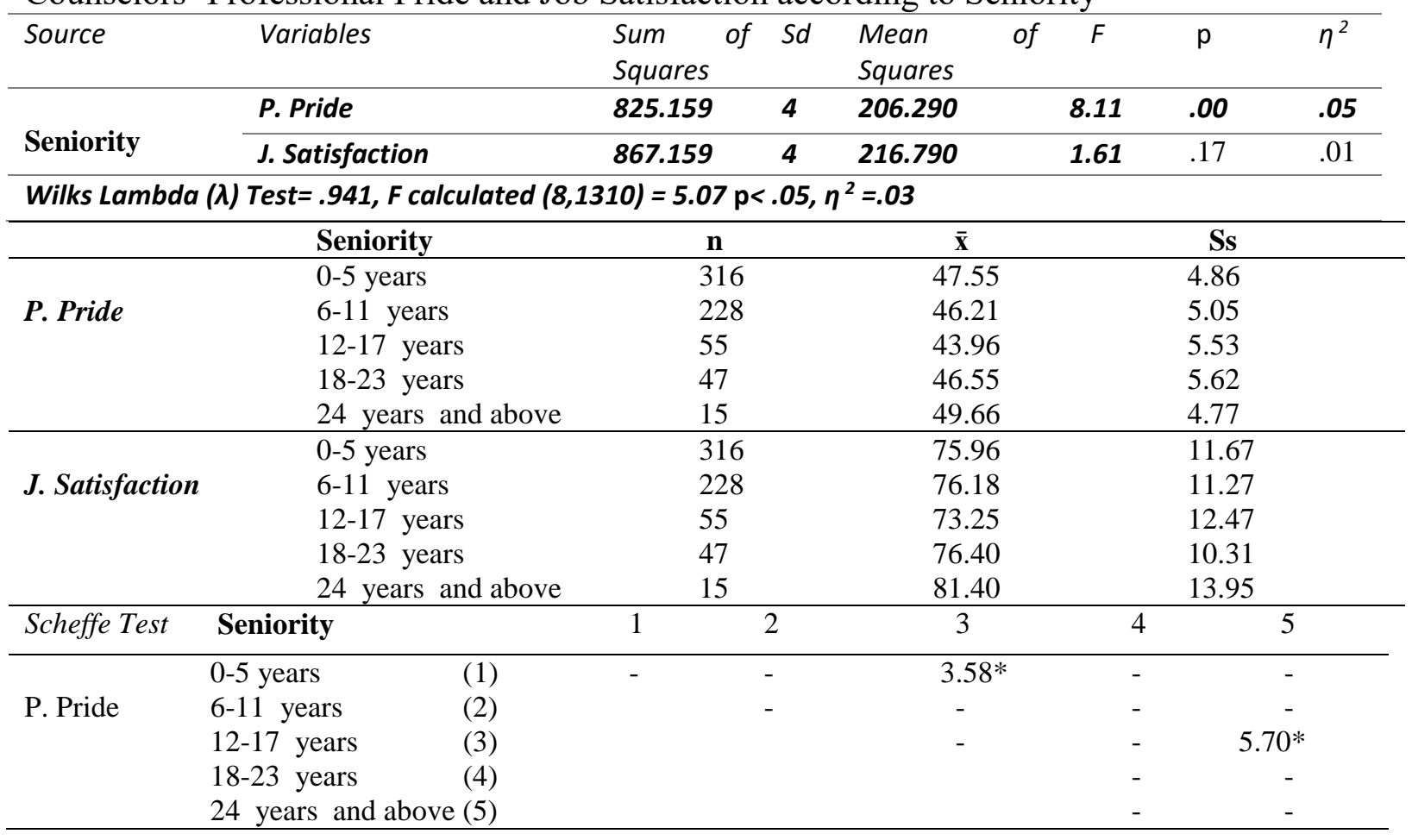

As seen in Table 9, the counselors' professional pride and job satisfaction scores significantly 
differ according to seniority. The impact value was low (Wilks Lambda $(\lambda)$ Test $=.941, \mathrm{~F}$ calculated $\left.(8,1310)=5.07 p<.05, \eta^{2}=.03\right)$. As shown by the ANOVA results given in the MANOVA extension in Table, professional pride scores ( $\mathrm{F}$ calculated $=8.11, p<.05, \eta^{2}=$ .05) significantly differ among the counselors according to seniority. However, job satisfaction scores (F calculated $=1.61, p>.05, \eta^{2}=.01$ ) do not significantly differ according to seniority. The magnitude of impact (Eta Square) values are $\eta 2=.05$ for professional pride and $\eta^{2}=.01$ for job satisfaction, with a low calculated impact. As demonstrated by the results of the Scheffe Test, the mean professional pride score was higher for the counselors with 0-5 years of work experience than those with 12-17 years of work experience, while the counselors with 12-17 years of work experience had a lower mean professional pride score than those with a work experience of 24 and more years.

\section{Discussion}

The study results showed that the counselors' professional pride and job satisfaction levels do not significantly differ according to gender. In a limited number of studies investigating counselors' professional pride according to gender, Littlefield (2016) found that professional pride does not significantly differ according to gender. However, Borst and Lako (2017) found a significant difference between the professional pride levels of public servants according to gender. A possible reason for such difference may have to do with the fact that the study was conducted with a different professional group and there was a close number of female and male participants in the sample group. Female participants constitute the majority of the counselors in the sample both in our study and Littlefield's (2016) study.

Our study results also revealed no significant difference between genders in the counselors' job satisfaction levels. In support of our finding, Bayrı (2006), Ekşi, Ismuk and Parlak (2015), Kadığlu (2014), Uslu (1999), Wiggins (1984) and Tahincioğlu (2018) also found that job satisfaction levels of school counselors do not significantly differ according to gender. A majority of the counselors in Turkey work in schools. And this study was also conducted with school counselors. School counselors from both sexes are offered the same opportunities, and hence the lack of any difference between genders occurs. Yet, Hamamc1, Oskargil-Göktepe and İnanç (2005), Gündoğdu (2013), and Bhat and Zargar (2015) found in their research that job satisfaction is predicted by gender, while Köksal (2019) found that male counselors have significantly higher job satisfaction levels than female counselors.

Based on the study results, we found that the counselors' professional pride levels do not significantly differ according to their education status. The counselors with a $\mathrm{PhD}$ degree were found to have a lower level of professional pride when compared to those with master's and bachelor's degrees. The low level of professional pride among the $\mathrm{PhD}$ degree holders could be attributed to the fact that the Ministry of Education does not make any changes in title and payment for school counselors despite any improvement in their education levels. In addition, school counselors may experience cases where their professional expectations are not met despite their higher education levels, they do not own an adequate understanding of the profession, and they have problems regarding professional boundaries, all of which might create negative feelings among them about their profession. Yüksel-Şahin (2008) and TuzgölDost and Keklik (2012) identified the most common challenges facing counselors as the lack of knowledge about counseling and guidance services, biased attitudes, and lack of collaboration with the guidance services on the part of other education stakeholders working in their schools, as well as unclear job definitions. Among a limited number of studies dealing with counselors' professional pride, some arrived at different results from our study findings. 
For instance, Lewis and Hatch (2008) suggested that when supported with education, school counselors will have a strong professional identity and thus have positive feelings for their profession. On the other hand, Gümüş (2017) concluded that professional pride does not differ according to education level, a result which could be attributed to the fact that Gümüş (2017) conducted the research with school counselors who both work in Turkey and have bachelor's and master's degrees.

As a result of our study, we found that the counselors' job satisfaction levels significantly differ according to education level. Job satisfaction was found to be higher among the counselors with a master's degree than those with bachelor and $\mathrm{PhD}$ degrees. A literature review shows different study results. Wiggins (1984); Brown, Swigart, Bolen, Hall, and Webster (1998); Koç (1998); and Gambrell, Rehfuss, Suarez, and Meyer (2011) all concluded that job satisfaction does not differ according to education level. On the other hand, Yelboga (2007) suggests that employees with higher education levels tend to care about productivity more in their professional practice and have more positive affectivity toward their jobs. Metle (2001), DeMato and Curcio (2004), Gürbüz (2007), Durmuş (2015), and Köksal (2019) found as a result of their studies that education level is a significant factor for increased job satisfaction. In contrast, Park and Kim (2002) and Kantar (2008) concluded that increased education level results in a decrease in job satisfaction. Individuals experience job satisfaction if they arrive at a positive result in the sense that their gains through education are equal to or more than those of others but have job dissatisfaction in the opposite case. Job satisfaction is higher among the counselors with master's degree in our study, a result which might have to do with the fact that counseling education is offered at the undergraduate level in Turkey and therefore, the number of $\mathrm{PhD}$ degree holders in particular is relatively low. Moreover, inadequate opportunities for practicum and supervision in counseling education in Turkey could also have resulted in reduced job satisfaction among $\mathrm{PhD}$ graduates. In addition, due to the incongruence between the annual number of graduates of the counseling and guidance programs and the number of those appointed to public positions, bachelor's degree holders complete their master's education until they get appointed and start working during or after their master's education, which may be another reason for the high job satisfaction levels among the master's degree holders.

We found in our study that the counselors' levels of professional pride and job satisfaction do not significantly differ according to whether they received supervision for individual and group counseling. Crutchfield and Borders (1997); Events (1997); Agnew, Vaught, Getz and Fortune (2000); and Azeem (2010) concluded in their research that counselors have more positive feelings toward the profession and greater job satisfaction when they participate in supervision sessions. In a similar vein, Özyürek (2009) and Yüksel-Şahin (2019) also argue that it is important for counselors to have the opportunity to put into practice the theoretical knowledge they gained during supervision and applied courses at university so that they can feel competent and effective in their professional practice. Thus, counselors who feel selfcompetent and qualified professionally can practice the profession with positive feelings and fulfill their professional expectations (Emerson, 2010). Our study results that the counselors' levels of professional pride and job satisfaction do not differ according to receiving supervision for individual and group counseling, which might have links with the inadequacies in undergraduate and graduate counseling education in Turkey with regard to supervision and practical training. Counseling education in the US, for instance, is only offered at graduate level in universities and involves three stages. The first stage is "prepracticum", which defines the theoretical part of education, while the second stage is "practicum" defining applied education and the third stage is "internship". The 
"prepracticum" stage involves the theoretical teaching of counseling principles, techniques, and skills, while at the "practicum" stage, counselors are expected to complete a minimum of 100 hours of supervised counseling sessions in which the knowledge and skills taught in classes are applied to clients. At the "internship" stage, counselors are supposed to complete a minimum of 600 hours of supervised counseling (CACREP, 2016). In Turkey, the courses targeting dissemination of theoretical information are 134 hours in total and of these courses, the theoretical courses such as counseling theories and the principles and techniques of counseling are similar to prepracticum courses. The applied courses including those on individual counseling and vocational guidance applications, fieldwork, internship, and observation in schools are 26 hours in total. Currently, there is no inter-university standard as to how many sessions are required for these applied courses, where they should be held, and the frequency and methodology of supervision, which constitutes an important problem in counseling education (Meydan, 2014; YÖK, 2018). Siviş-Çetinkaya and Karaırmak (2012) also underline that individual counseling applications in undergraduate programs are compulsory for all counseling and guidance programs in every university but it is not clearly known with what methodology and quality the supervision is provided and even whether it is provided in all universities. On the other hand, $\mathrm{PhD}$ programs that train academic specialists do not offer any theoretical and applied courses on supervision; therefore, there are problems concerning the quality of academic specialists in the field. According to the national standards, basic and advanced competency is required for group counseling. At the basic level, prospective counselors are required to possess the competencies for constructing the group process, group aims and dynamics, and mastery over the theories, principles, techniques and skills of group counseling both in theory and practice, and so on. In addition, prospective counselors are also required to have a minimum of ten hours of group experience as a group member within an academic semester. At advanced level, prospective counselors are required to perform supervised work for a minimum of 30 hours in business-oriented and psycho-educational groups and work as a group leader in group counseling for a minimum of 45 hours under supervision (CACREP, 2016). Although there is no standard for group counseling applications in Turkish universities, most universities are offering theoretical and practical information in a three-hour group counseling course (Meydan, 2014).

Based on our findings, we concluded that counselors' professional pride and job satisfaction levels significantly differ according to whether they perceive university education as adequate. Counselors who see university education as inadequate had lower levels of professional pride and job satisfaction when compared to those who see university education as moderately or highly adequate. In their studies, Balc1 (2017) and Boyac1 (2018) identified the weaknesses of counselor education as focusing on theory at the expense of practical aspects, lack of supervision, the short duration of school internships and limited activities for prospective counselors during internship, and the inadequate number of elective courses offered to students. Under such circumstances, counselors feel inefficient both in individual and group counseling settings. Paisley and Borders (1995) note that counselors with inadequate university training usually need supervision when faced with different problems at work and when working with different cases. Adequacy of undergraduate education of counselors is a determining factor for the emergence of needs and problems. In cases when such needs are not met and problems are not solved, it is accentuated that counselors will experience negative feelings and thoughts in their practice and will be deprived of job satisfaction. Likewise, Aydemir-Sevim and Hamamc1 (1999) and Uslu (1999) found that job satisfaction is higher among counselors who feel professionally competent. Tuzgöl-Dost and Keklik (2012) argue that by improving the adequacy of counseling and guidance programs, counseling applications will become more active and counselors will have greater job 
satisfaction with qualified counseling service. In another study, Larson (1998) concluded that counselors' professional interest and commitment is increased when they practice as effective counselors as a result of their university training. All these findings can explain the fact that counselors who see their university training as adequate also perceive themselves as professionally competent and thus have positive feelings and thoughts during their practice.

In our study, we found that counselors' professional pride and job satisfaction levels significantly differ according to the job title they use. Based on the results, counselors who use the job title of counselor have lower professional pride and job satisfaction than those using the psychological counselor title. In Turkey, the problem of job title for the staff to perform Psychological Counseling and Guidance services goes as far back as the start of these services in the country (Arslan and Sommers-Flanagan, 2018). The job title problem still persists since there is no mention of the "Counselor" position in the State Personnel Law (Turkish Psychological Counseling and Guidance Association, 2013). Although various titles have been used over the years for the alumni of counseling and guidance programs who are employed in schools in Turkey such as education specialist, school counselor, counselor, guidance worker, and psychological counseling and guidance specialist (Doğan, 1996; Yüksel-Şahin, 2019), most academic specialists agree upon the title of "Psychological Counselor" (Yeşilyaprak, 2007; Yüksel-Şahin, 2019). Even though counselors are not teachers by profession, the "counselor" job title was created for counselors by the Ministry of National Education for employment purposes in 1983 and the title was still the same in the guidance services regulation published in 2017 (www.mevzuat.meb.gov.tr) (Yüksel-Şahin, 2012). Being labelled with different titles and roles in the literature and in practice adversely affects counselors' professional identity and job satisfaction (Yeşilyaprak, 2000; Aldemir and Illhan, 2018). In fact, in a study on the titles used by counselors, Gümüş (2017) argued that this problem about titles in Turkey constitutes a great obstacle for the counselors' professional identity. Furthermore, similarly to our research results, the author concluded that the counselors who use "psychological counselor" as a job title have more positive feelings and thoughts about their profession, have greater professional competence and are more proud of their profession when compared to those who use the title "guidance teacher".

In our study, we also found that counselors' professional pride levels significantly differ according to seniority. Thus, the counselors with 0-5 years of experience in the field have higher professional pride levels than those with 12-17 years of experience. And the counselors with 12-17 years of experience have lower professional pride than those with an experience of 24 years and above. Schultz and Schultz (2007) argue that during their first years of career, people are excited about learning their roles and responsibilities, improving themselves, and putting their theoretical knowledge into practice. This may lead counselors in their first years of service to have positive feelings about their profession, devote themselves to their practice, and be proud of the profession, which may result in greater professional pride. Such positive feelings are on the rise again after long years of service, which might have to do with fulfilled expectations at the end of one's career. In a similar vein, we also found that counselors' job satisfaction levels significantly differ according to seniority. Thus, counselors with an experience of 24 years and more were found to have greater job satisfaction when compared to all other seniority groups. It is suggested that individuals have fulfilled their expectations after spending a long time in their career. For this very reason, Ronen (1978), Oshagbemi (2000), Garret and Karım (2005), Sadık (2014), and Bhat and Zargar(2015) all concluded in their research on job satisfaction that seniority is a determining factor for job satisfaction. In their studies dealing with job satisfaction among counselors, Kadığlu (2014) and Ekşi, and Ismuk and Parlak (2015) also found that counselors who have spent a longer time in their 
careers experience greater professional satisfaction when compared to other seniority groups, while in another study on teachers' job satisfaction, Klecker (1997) concluded that teachers with an experience of 26 years and above have greater job satisfaction than others. Yet, in other research with different findings than our study results, DeMato and Curcio (2004) found that school counselors in general are satisfied with their professional practice but their selfperceived satisfaction was less than the previous decade.

\section{Conclusion and Suggestions}

According to our study results, counselors' levels of professional pride and job satisfaction were found to not differ significantly according to gender or receiving supervision for individual and group counseling. On the other hand, their professional pride and job satisfaction significantly differ according to education level, seeing university education as adequate, and the job title they use. As for seniority, counselors' professional pride levels significantly differ, but their job satisfaction levels do not significantly differ according to years of professional experience. The study variables are limited to the traits assessed by the Counselor Professional Pride Scale and the Job Satisfaction Scale. In this context, further researchers could be suggested to study counselors' professional pride and job satisfaction using different data collection instruments. Moreover, the study participants are limited to the psychological counselors employed in the public schools (viz. preschools, primary, secondary, and high schools) and Guidance Research Centers run by the Ministry of Education. Accordingly, researchers can be suggested to study and carry out comparative research on the professional pride and job satisfaction of counselors working in organizations other than educational institutions. Since professional pride is a recent area of focus in the literature; therefore, we believe that it will be useful to conduct studies on the subject with different variables. A very limited number of counselors who are pursuing their $\mathrm{PhD}$ studies or have already earned their $\mathrm{PhD}$ degrees. Thus, new research could be conducted on sample groups with equal distribution in education level. It is also important to work towards accreditation in counselor education as we elaborated on in the study; to increase the hours of applied courses; to improve the quality of supervision for counseling; and to replace the "teacher" title with the "school counselor" title.

\section{Note}

This article was produced from the first author's doctoral dissertation under the supervision of the second author.

\section{References}

ACA-American Counseling Association (2013). What is counseling?. Retrieved from https://www.counseling.org/search/\#/what\%20is\%20counseling/page=1

ACA- American Counseling Association. (2016). What is counseling?. Retrieved from https://www.counseling.org/about-us/about-aca adresinden indirilmiştir.

Agnew, T., Vaught, C. C., Getz, H. G. ve Fortune, L. (2000). Peer group clinical supervision program fosters confidence and professionalism, Professional School Counseling, 4, 6-12.

Alçekiç, K. G. (2011). Kariyer gelişimi açısından psikolojik danışmanların mesleki doyum ve değerlerinin incelenmesi [Research on psychological counselors' job satisfactions and values according to their career developments]. (Unpublished master's thesis), Marmara University, Education Sciences, İstanbul. 
Aldemir, A., \& İlhan, T. (2018). Okul psikolojik danışmanlarının mesleki algıları üzerine bir inceleme [A study on the professional perceptions of school counselors]. Turkish Psychological Counseling and Guidance Journal, 8(51), 53-80.

Arslan, Ü., \& Sommers-Flanagan, J. (2018). The new stage of the Turkish counseling system: explosive growth (2000 to the present). Journal of Multicultural Counseling and Development, 46, 115-128.

Aydemir-Sevim, S., \& Hamamcı, Z. (1999) Psikolojik danışmanların mesleki doyumları ile mesleki yeterlilikleri arasındaki ilişkinin incelenmesi [The investigation of the relationships between job satisfaction and job competence]. Turkish Psychological Counseling and Guidance Association, 2, 39-46.

Azeem, S., M. (2010). Job satisfaction and organizational commitment among employees in the Sultanate of Oman. Pschology, 1, 295-299. doi:10.4236/psych.2010.14038.

Baggerly, J., \& Osborn, D. (2006). School counselors' career satisfaction and commitment: Correlates and predictors. Professional School Counseling, 197-205.

Bhat, R. K., \& Zargar, S.R. (2015). Job satisfaction of male and female teacher at primary level of district Shopian, Kashmir. Researcher, 7(2),16-19.

Balcı, S. (2017). Okul psikolojik danışmanı öz yetkinlik ölçeği'nin türk kültüründeki psikometrik özellikleri [Psychometric properties of school counselor self-efficacy scale in turkish culture]. Journal of Kirsehir Education Faculty, 18(2).

Bayrı, H. (2006). Ortaöğretim kurumlarında çalışan psikolojik danışman/rehber ögretmenlerin iş doyumuna ilişkin görüşlerinin değerlendirilmesi: Güneydoğu Anadolu Bölgesi örneği [Job satisfaction levels of counselors and guiding teachers employed at secondary and high schools in the Southeastern Anatolia region]. (Unpublished master's thesis). Dicle University, Diyarbakır.

Borst, R. T., \& Lako, C. J. (2017). Proud to be a public servant? An analysis of the workrelated determinants of professional pride among Dutch public servants. International Journal of Public Administration, 40(10), 875-887.

Boyacı, M. (2018). Türkiye'de Psikolojik Danışman Eğitimi ve Karşılaşılan Sorunlar: Güncel Bir Durum Değerlendirmesi [Counselor Education and Problems in Turkey: A Current Status Assessment]. ERPA 2018, 335.

Brown, M. B., Swigart, M. L. Bolen, L. Hall, C., \& Webster, R. (1998). Doctoral and nondoctoral school psychologist: are there differences? Psychology in School, 34, 347-354

Büyüköztürk, Ş. (2002). Sosyal bilimler için veri analizi el kitabı: Istatistik [Data analysis handbook for social sciences: Statistics]. Ankara: Pegema Pub.

Büyüköztürk, S., Şekercioğlu, G., \& Çokluk, O. (2016). Sosyal bilimler için çok değişkenli istatistik SPSS ve LISREL uygulamalart [Multivariate statistics SPSS and LISREL applications for social sciences]. Ankara: Pegem Academy Pub.

Crutchfield, L.B., \& Borders, L. B. (1997). Impact of two clinical supervision models on practicing school counselor. Journal of Counseling and Development, 75, 219-231.

Çakmak, Z., \& Gürdal, H. (2015). Araştırma görevlilerinin iş tatmin düzeyi ile iletişim düzeyinin ayırt edici öğelerinin diskriminant analizi ile belirlenmesi [Determination of distinctive elements of job satisfaction level and communication level of research assistants with discriminant analysis]. International Journal of Social Sciences and Education Research, 1 (4), 1517-1534.

Çetinkanat, C. (2000). Örgütlerde güdüleme ve iş doyumu [Motivation and job satisfaction in organizations]. Ankara: An1 Pub.

Çetinkaya, R., \& Karaırmak, Ö. (2012). Psikolojik danışman eğitiminde süpervizyon [Supervision in counselor education]. Turkish Psychological Counseling and Guidance Association, 4(37), 107-121. 
Demato, D., \& Curcio, C. (2004). Job satisfaction of elementary school counselors. Professional School Counseling,7, 236-246.

Doğan, S. (1996). Türkiye'de psikolojik danışma ve rehberlik alanında meslek kimliğinin gelişimi ve bazı sorunlar [The development of Professional identity in psychological counseling and guidance field in Turkey and related problems]. Turkish Psychological Counseling and Guidance Association, 2(7), 32-43.

Doğan, S. (2000). The historical development of counseling in Turkey. International Journal for the Advancement of Counseling, 22, 57-67.

Doğan, S. (2000). Psikolojik danışman eğitiminde akreditasyonun gereği ve bir model önerisi [The need for accredition in counselor education: A recommended model]. Turkish Psychological Counseling and Guidance Association, 2 (14), 31-38.

Durmuş, A. (2015). Psikolojik danışmanların öz yeterlikleri ile iş doyumu ve yaşam doyumu arasındaki ilişki [The relation between the self-efficacy, job satisfaction and life satisfaction of psychological counselors]. (Unpublished master's thesis). Karadeniz Technical University, Trabzon.

Ekşi, H., Ismuk, E., \& Parlak, S. (2015). Okul psikolojik danışmanlarında iş doyumunun yordayıcısı olarak psikolojik danışma özyeterliği ve dinlenme becerileri [In psychological counselor self-efficacy beliefs and active listening skills as predictor of job satisfaction]. Abant İzet Baysal University Education Faculty Journal, 15(2), 84103.

Emerson, C. H. (2010). Counselor proffesional identity: Construction and validation of Counselor Proffesional Identity Measure (Doctoral Thesis). Retrieved from http://libres.uncg.edu/ir/uncg/f/emerson_uncg_0154d_10396.pdf (Thesis no: 10396).

Events, N.W.(1997). Counselor satisfaction linked to supervision, advancement. Alcoholism \& Drug Abuse Weekly, 9, 3-5.

Galanou, E. Georgakopoulos, G. Sotiropoulos, I. ve Dimitris,V. (2010). The effect of reward system on job satisfaction in an organizational chart of four hierarchical levels: A qualitative study. Canadian Social Science, 6 (5), 102123.

Gambrell, C. E., Rehfuss, M. C., Suarez, E. C., \& Meyer, D. (2011). Counselors' job satisfaction across education levels and specialties. The Journal of Counselor Preparation and Supervision, 3(1), 3.

Garret, R. M., Karım, S. (2005). Job satisfaction of university academics. Universty of Bristol, Higher Education, 50(1), 33-56.

Gladding, S. T. (2013). Psikolojik danışma. Kapsamlı bir meslek [Psychological counseling. A comprehensive profession]. Ankara: Nobel Academy Pub.

Gümüş, A. E. 2017. Okul psikolojik danışmanlarının kullandıkları unvanın mesleki kıvanç, psikolojik danışman özyeterliği ve bazı öz niteliklerle yordanması [Predicting the professional title of the school counselors with the professional pride and counselor self-efficacy]. Ege Education Journal, 18(2), 653-675.

Gündoğdu, G. B. (2013). Sinıf öğretmenlerinin iş doyumu ve mesleki tükenmişlik düzeyleri üzerine bir çalışma [A research on career satisfaction and professional burnout levels of class teachers: The case study of Mersin] (Unpublished master's thesis). Çağ University, Mersin.

Gürbüz, A. (2007). Eğitim Seviyesinin İş Tatmini Üzerindeki Etkisinin Turizm Sektörü Açısından Degerlendirilmesi [An Assesment on the Effect of Education Level on the Job Satisfaction From the Toursim Sector Point of View]. Doğuş University Journal, 8(1), 36-46.

Hamamc1, Z., Oskargil-Göktepe, E., \& İnanç, N. (2005). Ankara ilinde çalışan okul psikolojik danışmanlarının mesleki gelişim ve mesleki doyum düzeyleri arasındaki ilişki [The relationship between professional development and '.locational satisfaction of school 
counselors working in Ankara Province]. Turkish Psychological Counseling and Guidance Association, 3, (24).

Haverkamp, B. E., Robertson, S. E., Cairns, S. L., \& Bedi, R. P. (2011). Professional issues in Canadian counselling psychology: Identity, education, and professional practice. Canadian Psychology/psychologie canadienne, 52(4), 256.

Hayes, B., Bonner, A., \& Pryor, J. (2010). Factors contributing to nurse job satisfaction in the acute hospital setting: a review of recent literature. Journal of Nursing Management, $18,804-814$

İbrahim, G. A., \& Dikmenli, Y. (2019). Sınıf öğretmenlerinin iş doyumu ve iş yaşamındaki yalnızlık düzeylerinin incelenmesi [An investigation of elementary teachers' job satisfaction and loneliness levels in work life]. Ahi Evran University Journal of Social Sciences Institute, 5(1), 131-150.

İnce, N. B., \& Şahin, A. E. (2016). Birleştirilmiş ve bağımsız sınıflarda çalışan sınıf öğretmenlerinin mesleki doyum ve tükenmişlik düzeylerinin karşılaştırılması [A comparison of combination classroom teachers' and single-grade teachers' job satisfaction and burnout levels]. Hacettepe University Journal of Education Faculty, 31(2), 391-409.

Jansen, T., Brink, G. J. M., \& Van den Kole, J. (2010). Professional Pride: A powerful force. Amsterdam, The Netherlands: Boom.

Kadıŏ̆lu, F. (2014). Psikolojik Danışmanların (Rehber Öğretmenlerin) Mesleki Doyum İle Kendine Sayglarl Arasındaki Ilişkinin Incelenmesi [The investigation of the relationship between psychological counselors' job satisfaction and self-esteem]. (Unpublished master's thesis). Marmara University, İstanbul.

Kantar, H. (2008). Issletmede Motivasyon [Motivation in businees]. İstanbul.

Karadağ, G., Sertbaş, G., Güner, İ.Ç., Taşdemir, H. S., \& Özdemir N. (2002). An İnvestigation Job Satisfaction, Burnout And Some Related Factors Among Nurses. Nurse Forum, 5(5), 8-15.

Kernaghan, K. (2001). An honour to be coveted. Pride, recognition and public service. Canadian Public Administration, 44, 67-83.

Kim, N. J., Lee, E. H., Jeon, J. H., \& Kim, E. J. (2019). Effects of role conflict, job satisfaction and professional pride on retention intention of nurses working at longterm care hospital. Journal of muscle and joint health, 26(2), 81-89.

Klecker, B., \& Loadman W. E. (1996). Exploring the relationship between teacher empowerment and teacher job satisfciton. To The Educational Resources Information Center, 5, 143-150.

Koç, Z. (1998). Rehberlik ve araştırma merkezlerinde görev yapan rehber ögretmenlerin iş doyumlarının bazı değişkenlere göre incelenmesi [Examining the job satisfaction of guidance teachers working in guidance and research centers according to some variables]. (Unpublished master's thesis). Gazi University, Ankara.

Köksal, H. K. (2019). Okul psikolojik danışmanlarının özel eğitim öz yeterlik algıları ile iş doyumlarl arasındaki ilişki: Mersin İli Örneği [Relationship between special education self-efficacy perceptions and job satisfactions of school counsellors: Mersin example] (Unpublished master's thesis). Çağ University, Mersin.

Kuzgun, Y., Sevim, S. A., \& Hamamcı, Z. (2016). Mesleki doyum ölçeğinin geliştirilmesi [Development of job satisfaction scale]. Turkish Psychological Counseling and Guidance Association, 2(11).

Larson, L. M. (1998). The social cognitive model of counselor training. The Counseling Psychologist, 26, 219-273.

Leeman, Y., \& Volman, M. (2019). Citizenship in prevocational education: Professional pride as a source. Education, Citizenship and Social Justice. 
Lewis, R. E., \& Hatch, T. (2008). Cultivating strengths-based professional identities. Professional School Counseling, 12(2).

Littlefield, L. J. (2016). An exploratory study of career counselor professional identity (Doctoral dissertation). University of Georgia.

Locke, E. A. (1998). Workers in Singapore. Journal of Behaviour Med., 21(3), 269-83

Lokatt, E., Holgersson, C., Lindgren, M., Packendorff, J., \& Hagander, L. (2019). An interprofessional perspective on healthcare work: physicians and nurses coconstructing identities and spaces of action. Journal of Management \& Organization, $1-17$.

Matrunola, P. (1996). Is There A Relationship Between Job Satisfaction And Absenteeism. Journal of Advanced Nursing, 23(4), 827-834

Mercer, D. (1997). Job satisfaction and the secondary head teacher: The creation of a model of job satisfaction. School Leadership \& Management, 17(1), 57-68.

Metle, M. A. K. (2001). Education, job satisfaction and gender in Kuwait. International Journal of Human Resource Management, 12(2), 311-332.

Meydan, B. (2014). Psikolojik danışman adaylarına psikolojik danışma becerilerinin kazandırılması: Karşılaştırmalı bir inceleme [Teaching counseling skills to counselor trainees: A comparative study. Hacettepe University Journal of Education Faculty, 29(3), 110-123.

Miner, S. (1992). Standing on the Shoulders of others: Career interdependence in job mobility. Administrative Science Quarterly,37(2), 262-281.

Myers, J. E., Sweeney, T. J., \& White, V. E. (2002). Advocacy for counseling and counselors: A professional imperative. Journal of Counseling \& Development, 80(4), 394-402.

Park, E. J., \& Kim, K. N. (2002). Job achievement and job satisfaction of dietitian in elementary school. J Korean Diet Assoc, 8(2), 163.

Oshagbemi T. (2000). Satisfaction with Co-Workers Behaviour. Employee Relations, 22 (1), 88-106.

Özgüven, E. (1999). Çăğdaş eğitimde psikolojik danışma ve rehberlik [Psychological counseling and guidance in contemporary education]. Ankara: PDREM Pub.

Özyürek, R. (2009). Okullarda psikolojik danışma ve rehberlik uygulamaları ve öğrencilere sağlanan süpervizyon olanakları: Ulusal bir tarama çalışması [The supervision opportunities for practicum students of school counseling provided to trainees in turkish universities: A national survey].Turkish Psychological Counseling and Guidance Association, 4(32), 54-63.

Paisley, P., \& Borders, L. D. (1995). School counseling: An evolving specialty. Journal of Counseling \& Development,74, 150-153.

Patterson, L. E., \& Welfel, E. R. (1994). The counseling process. Thomson Brooks/Cole Publishing Co.

Pietrofesa, J.J., Hoffman, A., \& Splete, H,H. (1984). Counseling: An Introduction. Boston: Houghton Mifflin Company.

Recepoğlu, E., \& Tümlü, G. Ü. (2015). Üniversite akademik personelinin mesleki ve yaşam doyumları arasındaki ilişkinin incelenmesi [Analyzing the relationship between life and job satisfaction of university academic staff]. Kastamonu Education Journal, 23(4).

Remley, T. P., \& Herlihy, B. (2007). Ethical, legal, and professional issues in counseling. Upper Saddle River, NJ: Prentice Hall.

Ronen, S. (1978). Job satisfaction and the neglected variable of job seniority. Human Relations, 31(4), 297-308.

Sadık, Ö. (2014). Sınıf öğretmenlerinin maruz kaldıkları yıldırma davranışları algıladıkları sosyal destek ve mesleki iş doyumlarl arasindaki ilişki [Examination on the 
relationship between primary-school teachers' mobbing experinces, perceived socialsupport and job-satisfaction]. (Unpublished master's thesis), İstanbul Aydın University, İstanbul.

Samuel, S., Sharma, V., \& Sharma, K. (2020). Analysis of factors influencing teacher job satisfaction and motivation in private professional institutes of bhopal city. Our Heritage, 68(15), 238-242.

Schultz, D. P., \& Schultz, S. E. (2007). Modern Psikoloji Tarihi [Modern History of Psychology]. İstanbul: Kaknüs Psychology Pub.

Siviş-Çetinkaya, R., \& Karaırmak, Ö. (2012). Psikolojik danışman eğitiminde süpervizyon [Supervision in counseling training]. Turkish Psychological Counseling and Guidance Association, 4(37), 107-121.

Swickert, M. L. (1997). Perceptions regarding the professional identity of counselor education doctoral graduates in private practice: A qualitative study. Counselor Education and Supervision, 36(4), 332-340.

Şimşek, Ş. M., Akgemci, T., \& Çelik, A. (2007). Davranış bilimlerine giriş ve örgütlerde davranıs [Introduction to behavioral science and behavior in organizations]. Ankara: Nobel Pub.

Tahincioğlu, D. (2018). Psikologların ve Psikolojik Danışmanların iş doyumu, çalışma yaşam kaliteleri ve merhamet düzeylerinin karşılaştırılması [Comparison of job satisfaction, work-life quality and compassion level between psycologists and psychological counselors]. (Unpublished master's thesis). Üsküdar University, İstanbul.

Tezer, E. (1991). İş doyumu ölçeği [Job satisfaction scale]. Hacettepe University Journal of Education Faculty, 9, 55-76.

Torres, D. G. (2019). Distributed leadership, professional collaboration, and teachers' job satisfaction in US schools. Teaching and Teacher Education, 79, 111-123.

Tuzgöl-Dost, M., \& Keklik İ. (2012). Alanda çalışanların gözünden psikolojik danışma ve rehberlik alanının sorunları [Professional Issues in Counseling as Perceived by Individuals Working in Counseling Settings]. Mehmet Akif Ersoy University Journal of Education Faculty, 1(23), 389-407.

Türk Psikolojik Danışma ve Rehberlik Derneği (2013). Psikolojik danışmanlığın dünü, bugünü, yarını [The past, present and future of psychological counseling].

Uslu, M. (1999). Eğitim kurumlarında çalışan psikolojik danışmanların ve rehber uzmanlarının iş doyumu ve tükenmişlik düzeylerinin danışmanların denetim odağı ve bazı değişkenlere göre incelenmesi [A Comparison of job satisfaction and burnout levels of psychological councelling and guiding professionals working at legal educational institutions according to locus of control and other variables]. (Unpublished master's thesis). Selçuk University, Konya.

VanZandt, C. E. (1990). Professionalism: A matter of personal initiative. Journal of Counseling \& Development, 68(3), 243-245.

Vermeeren, B., \& Van Geest, D. (2012). Researchnote: Professional pride and pressures of rules in the public sector. Tijdschrift Voor Arbeidsvraagstukken, 28, 215-328. (No doi).

Wiggins, D. (1984). Personality-environmental factors related job satisfaction of school counselors.Vocational Guidance Quarterly, 22, 171177.

Yelboğa, A. (2007). Bireysel demografik değişkenlerin iş doyumu ile ilişkisinin finans sektöründe incelenmesi [The examination demographic variables with job satisfaction in finance sector]. Çă̆ University Journal of Social Sciences, 4(2), 1-18.

Yeşilyaprak, B.(2000). Ankara ilköğretim okullarında görevli rehber öğretmenler üzerinde betimsel bir araştırma: demografik özellikleri, mesleki sorunlarl ve iş doyumu düzeyleri [A descriptive research on school counselors in Ankara primary schools: 
demographic characteristics, professional problems and job satisfaction levels] (Unpublisshed associate thesis). Gazi University, Ankara.

Yeşilyaprak, B. (2007). Türkiye'de psikolojik danışma ve rehberlik alanının gelişiminde Türk Psikolojik Danışma ve Rehberlik Derneğinin yeri ve önemi [The importance of Turkey in the field of counseling and guidance in the development of Turkish Psychological Counseling and Guidance Association]. Ankara: Nobel Pub.

Yerin-Güneri, O., Büyükgöze-Kavas, A., \& Koydemir, S. (2007). Okul psikolojik danışmanlarının psikolojik gelişimi: Acemilikten olgunlaşmaya giden yol [Psychological development of school counselors: The road from novice to maturity]. Ankara: Nobel Yayın Dağıtım.

YÖK (2018). Rehberlik ve psikolojik danışmanlık lisans programı [Guidance and psychological counseling undergraduate program]. Retrieved from https://www.yok.gov.tr/Documents/Kurumsal/egitim_ogretim_dairesi/Yeni-

Ogretmen-Yetistirme-Lisans-Programlari/ Rehberlik_ ve _Psikolojik _Danismanlik _Lisans Programi.pdf.

Yurtkoru, E. S., \& Sipahi, B. (2003). Öğretim üyesi performans değerlendirme kriterinin cinsiyete göre belirlenmesi üzerine analitik bir çalışma [An analytical study on the determination of academic staff performance evaluation criteria by gender]. Journal of İstanbul Chamber of Comerce, Retrieved from http://acikerisim.ticaret.edu.tr/xmlui/bitstream/handle/11467/218/M00051.pdf?sequen $\mathrm{ce}=1$.

Yüksel-Şahin, F. (2008). Ortaöğretimdeki öğrenci görüşlerine göre psikolojik danışma ve rehberlik hizmetlerinin değerlendirilmesi [Evaluation of school counseling and guidance servicesbased on views of high school students]. International Journal of Human Sciences, 5(2).

Yüksel-Şahin, F. (2012). Türk Milli Eğitim Şuraları'nda (1939-2010) psikolojik danışma ve rehberlik ile ilgili alınmış olan kararların değerlendirilmesi [An evaluation of the decisions taken about psychological counseling and guidance in the Turkish National Education Councils (1939-2010)]. Journal of Social Studies Education Research, 3(1), 95-118.

Yüksel-Şahin, F. (2019). Psikolojik danışmanlar için el kitabı [Handbook for psychological counselors]. Ankara: Nobel Pub. 